\title{
BLOOD PRESSURE IN THE NEWBORN ESTIMATED BY THE FLUSH METHOD
}

\author{
BY \\ JOHN O. FORFAR and MAURICE A. KIBEL \\ From the Western General Hospital, Edinburgh, and the Department of Child Life and Health, \\ University of Edinburgh
}

(RECEIVED FOR PUBLICATION DECEMBER 13, 1955)

The increasingly widespread practice of careful routine examination of the newborn infant, particularly where it reveals a cardiac murmur, has increased the need for a simple method of measuring neonatal blood pressure.

As assessed indirectly, widely varying blood pressures have been recorded in the newborn. Sphygmomanometric estimation by the standard methods of auscultation and palpation is nearly always difficult and time-consuming and often impossible. Recently a simple rapid method, using the flush principle applied by Gaertner to blood pressure estimation more than 50 years ago, has been employed in newborn infants (Cappe and Pallin, 1952: Goldring and Wohltmann, 1952). This method has not yet been entirely standardized however. Its accuracy has been proclaimed (Reinhold and Pym, 1955), and has been doubted (Schaffer, 1955), and the normal range of newborn blood pressure as so measured has not yet been fully established.

This paper reports a series of 513 blood pressure estimations carried out by the flush method on 143 full-term normal newborn infants. Nearly all of these were carried out during the first 11 days of life. The readings were taken in pairs on the arm and leg, and as far as possible two pairs were taken on each infant during the 11-day period.

\section{Method}

The technique was modified from the methods described by Goldring and Wohltmann and Cappe and Pallin.

All readings were taken in good diffuse daylight with the baby in his cot in the right lateral position. The infants were clothed and the nursery temperature was 65-70 $\mathrm{F}$.

Readings were not made routinely after feeding and no sedation was used. A standard mercury sphygmomanometer was used and it was always applied to the left arm and left leg, each being used first in alternate cases. An average of two readings or, where any difficulty was experienced in determining the end-point, an average of three readings, was taken.

A 3-in. rubber Martin's bandage was firmly wrapped round the limb from the periphery to mid-calf or midforearm, and a 4-in. $\times 2$-in. sphygmomanometer cuff was then applied to the thigh or arm respectively. The pressure was then raised to about $130 \mathrm{~mm}$. of mercury and the rubber bandage rapidly removed, a pallid extremity being obtained with a well demarcated edge. The pressure was lowered $6 \mathrm{~mm}$. and left at this level for five seconds while the limb was inspected. This procedure was repeated until flushing developed. The first warning that the flushing point was approaching was obtained from the fine oscillation which developed in the mercury column. (This oscillation began 5 to $10 \mathrm{~mm}$. above the flushing point and was maximal on reaching this point.) The pressure was then lowered carefully, a few $\mathrm{mm}$. at a time, until flushing occurred. This consisted in a sudden loss of definition of the line of demarcation and a fine pink flush spreading distally at a varying pace depending upon the amount of activity of the infant. If the infant was asleep or very quiet the development of this fine flush was more tardy in appearing and more easily missed. Further lowering of the pressure produced a vivid red flush confined to the previously blanched area. This reaction was presumably due to plethora (secondary to ooclusion of the venous return) developing in the previously exsanguinated distal portion of the limb and was considered to be beyond the true endpoint.

If the limb was kept blanched for too long passive diffusion of the blood from deeper tissues occurred, blurring the zone of demarcation and interfering with the accuracy of readings. Hence it is important to arrive at the vicinity of the end-point as expeditiously as possible.

Occasionally difficulty was experienced in producing a satisfactory pallid zone. The true explanation of this is not known, but it may have been due to seepage of blood out of tissues splinted by the long bones from the pressure of the bandage.

Unlike Goldring and Wohltmann and Reinhold and Pym, we applied the cuff round the upper arm and thigh rather than the lower arm and lower leg lest the splinting 
effect of the double bones in the latter two situations might permit a leak of blood into the portion of the limb distal to the cuff and result in false readings.

\section{Results}

Age. Table 1 and Figs. 1, 2 and 3 show the mean pressures in arm and leg according to age with ranges calculated in terms of twice and thrice the

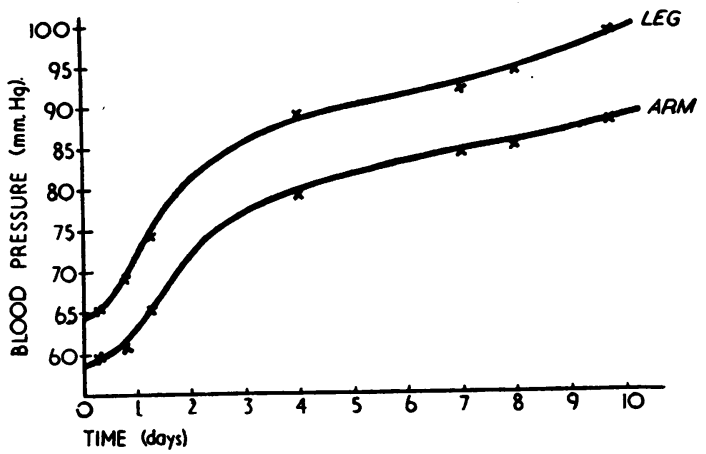

Fig. 1.

standard deviation from those means $(95.5 \%$ of readings would be expected to be within the range, mean $\pm 2 \times$ S.D. and $99.7 \%$ within the range, mean $\pm 3 \times$ S.D.). The mean birth weights of each of the age groups were sufficiently close for weight not to be a factor in the production of any alteration of blood pressure. The rise in blood pressure over the 11-day period is statistically significant.

On direct measurement of the blood pressure in the umbilical artery at birth, Woodbury, Robinson and Hamilton (1938) found a range of pressure of

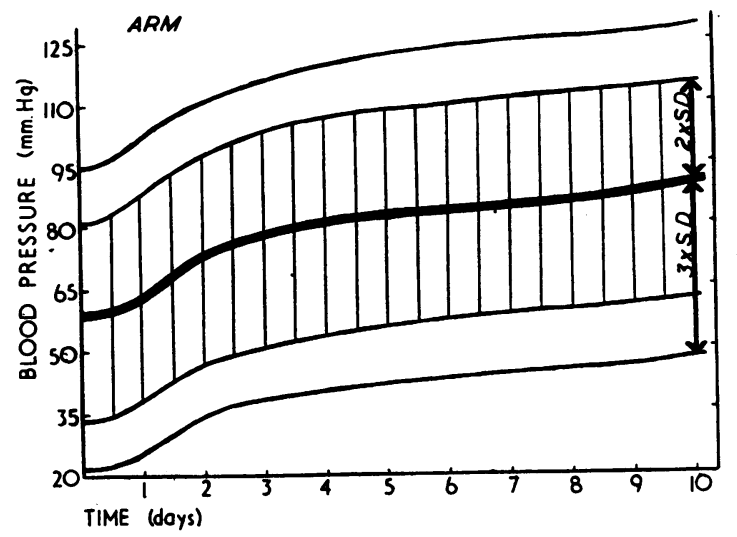

Fig. 2.

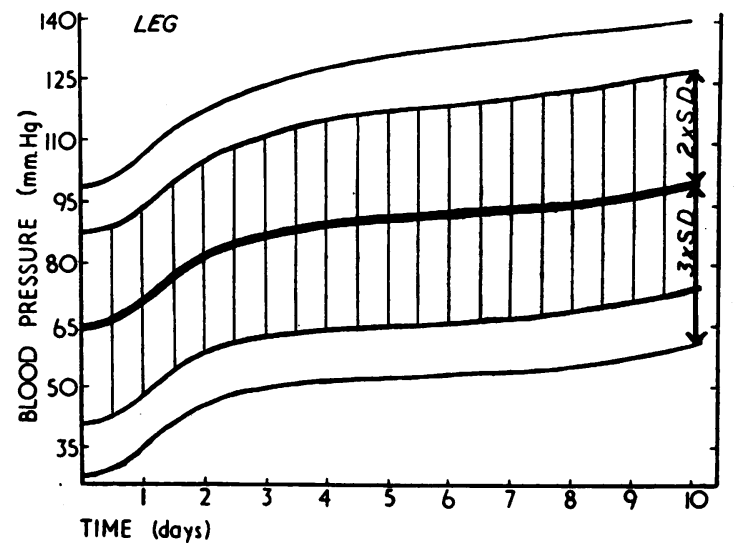

Fig. 3.

TABLE 1

BLOOD PRESSURE AND AGE

\begin{tabular}{|c|c|c|c|c|c|c|c|}
\hline Age & $\begin{array}{l}\text { Number } \\
\text { of } \\
\text { Readings }\end{array}$ & $\begin{array}{l}\text { Mean } \\
\text { Pressure }\end{array}$ & $\begin{array}{l}\text { Standard } \\
\text { Deviation }\end{array}$ & $\begin{array}{c}\text { Range } \\
\text { (Mean } \pm 2 \times \text { S.D.) }\end{array}$ & $\begin{array}{l}\text { Standard } \\
\text { Error of } \\
\text { Mean }\end{array}$ & $\begin{array}{c}\text { Coefficient } \\
\text { of } \\
\text { Variation }\end{array}$ & $\begin{array}{c}\text { Mean Birth } \\
\text { Weight } \\
\text { (lb.) }\end{array}$ \\
\hline (Av. $=7 \cdot 2 \mathrm{hr}$. ) & $\begin{array}{ll}\text { A. } & 37 \\
\text { L. } & 38\end{array}$ & $\begin{array}{l}59 \cdot 5 \\
65 \cdot 4\end{array}$ & $\begin{array}{l}12 \cdot 0 \\
11 \cdot 7\end{array}$ & $\begin{array}{l}35 \cdot 5-83 \cdot 5 \\
42 \cdot 0-88 \cdot 8\end{array}$ & $\begin{array}{l}4 \cdot 0 \\
3 \cdot 8\end{array}$ & $\begin{array}{l}20 \cdot 4 \\
17 \cdot 9\end{array}$ & $7 \cdot 5$ \\
\hline $\begin{array}{l}13-24 \mathrm{hr} . \\
\text { (Av. }=18 \cdot 8 \mathrm{hr} .)\end{array}$ & $\begin{array}{l}\text { A. } 43 \\
\text { L. } 45\end{array}$ & $\begin{array}{l}60 \cdot 5 \\
68 \cdot 8\end{array}$ & $\begin{array}{l}13 \cdot 6 \\
12 \cdot 7\end{array}$ & $\begin{array}{l}33 \cdot 2-87 \cdot 7 \\
43 \cdot 4-94 \cdot 2\end{array}$ & $\begin{array}{l}4 \cdot 2 \\
3 \cdot 8\end{array}$ & $\begin{array}{l}22 \cdot 4 \\
18 \cdot 3\end{array}$ & $7 \cdot 3$ \\
\hline $\begin{array}{l}24-48 \text { hr. } \\
\text { (Av. }=29.9 \text { hr.) }\end{array}$ & $\begin{array}{l}\text { A. } 23 \\
\text { L. } 23\end{array}$ & $\begin{array}{l}65 \cdot 1 \\
73 \cdot 7\end{array}$ & $\begin{array}{l}12 \cdot 4 \\
10 \cdot 5\end{array}$ & $\begin{array}{l}40 \cdot 3-89 \cdot 9 \\
52 \cdot 7-94 \cdot 7\end{array}$ & $\begin{array}{l}5 \cdot 2 \\
4 \cdot 4\end{array}$ & $\begin{array}{l}19 \cdot 0 \\
13 \cdot 6\end{array}$ & $7 \cdot 8$ \\
\hline 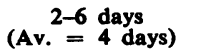 & $\begin{array}{l}\text { A. } 22 \\
\text { L. } 22\end{array}$ & $\begin{array}{l}79 \cdot 0 \\
88 \cdot 7\end{array}$ & $\begin{array}{l}13 \cdot 9 \\
13 \cdot 0\end{array}$ & $\begin{array}{l}51 \cdot 2-106 \cdot 8 \\
62 \cdot 7-114 \cdot 0\end{array}$ & $\begin{array}{l}3 \cdot 8 \\
5 \cdot 6\end{array}$ & $\begin{array}{l}17 \cdot 3 \\
14 \cdot 9\end{array}$ & $7 \cdot 5$ \\
\hline 7 days & $\begin{array}{l}\text { A. } 29 \\
\text { L. } 29\end{array}$ & $\begin{array}{l}84 \cdot 4 \\
91 \cdot 7\end{array}$ & $\begin{array}{l}12 \cdot 2 \\
12 \cdot 2\end{array}$ & $\begin{array}{l}60 \cdot 0-108 \cdot 8 \\
67 \cdot 3-116 \cdot 1\end{array}$ & $\begin{array}{l}4 \cdot 6 \\
4 \cdot 6\end{array}$ & $\begin{array}{l}15 \cdot 2 \\
13 \cdot 3\end{array}$ & $7 \cdot 1$ \\
\hline 8 days & $\begin{array}{l}\text { A. } 52 \\
\text { L. } 52\end{array}$ & $\begin{array}{l}85 \cdot 0 \\
94 \cdot 3\end{array}$ & $\begin{array}{l}14 \cdot 7 \\
15 \cdot 7\end{array}$ & $\begin{array}{l}55 \cdot 6-114 \cdot 4 \\
62 \cdot 9-125 \cdot 7\end{array}$ & $\begin{array}{l}4 \cdot 0 \\
4 \cdot 4\end{array}$ & $\begin{array}{l}16 \cdot 3 \\
15 \cdot 8\end{array}$ & $7 \cdot 4$ \\
\hline $\begin{array}{c}\text { 9-11 days } \\
\text { (Av. }=9 \cdot 7 \text { days) }\end{array}$ & $\begin{array}{l}\text { A. } 43 \\
\text { L. } 43\end{array}$ & $\begin{array}{l}88 \cdot 3 \\
99 \cdot 0\end{array}$ & $\begin{array}{l}13 \cdot 4 \\
12.0\end{array}$ & $\begin{array}{l}61 \cdot 5-115 \cdot 1 \\
75 \cdot 0-123 \cdot 0\end{array}$ & $\begin{array}{l}4 \cdot 0 \\
3 \cdot 6\end{array}$ & $\begin{array}{l}15 \cdot 2 \\
12 \cdot 4\end{array}$ & $7 \cdot 1$ \\
\hline
\end{tabular}


TABLE 2

BLOOD PRESSURE AND WEIGHT

\begin{tabular}{|c|c|c|c|c|c|}
\hline $\begin{array}{c}\text { Weight Group } \\
\text { (lb.) }\end{array}$ & $\begin{array}{l}\text { Mean } \\
\text { Pressure }\end{array}$ & $\begin{array}{l}\text { Standard } \\
\text { Deviation }\end{array}$ & $\begin{array}{l}\text { Standard } \\
\text { Error of Mean }\end{array}$ & $\begin{array}{l}\text { Number } \\
\text { in Group }\end{array}$ & $\begin{array}{c}\text { Average Age } \\
\text { of Group }\end{array}$ \\
\hline (Av. $\stackrel{5-7}{=} 6 \cdot 27)$ & $\begin{array}{l}\text { A. } \quad 70 \cdot 3 \\
\text { L. } 79 \cdot 5\end{array}$ & $\begin{array}{l}17 \cdot 3 \\
17 \cdot 4\end{array}$ & $\begin{array}{l}1 \cdot 7 \\
1 \cdot 7\end{array}$ & $\begin{array}{l}103 \\
103\end{array}$ & $4 \cdot 8$ days \\
\hline (Av. $\stackrel{7-8}{=} 7 \cdot 44)$ & $\begin{array}{l}\text { A. } \quad 76 \cdot 7 \\
\text { L. } 84 \cdot 2\end{array}$ & $\begin{array}{l}17 \cdot 0 \\
17 \cdot 6\end{array}$ & $\begin{array}{l}2 \cdot 0 \\
2 \cdot 0\end{array}$ & $\begin{array}{l}73 \\
75\end{array}$ & $4 \cdot 7$ days \\
\hline$($ Av. $\stackrel{8-11}{=} 8 \cdot 65)$ & $\begin{array}{l}\text { A. } \quad 80 \cdot 2 \\
\text { L. } 88 \cdot 3\end{array}$ & $\begin{array}{l}18 \cdot 2 \\
18 \cdot 9\end{array}$ & $\begin{array}{l}2 \cdot 1 \\
2 \cdot 2\end{array}$ & $\begin{array}{l}73 \\
74\end{array}$ & $4 \cdot 8$ days \\
\hline
\end{tabular}

A. $=$ Arm

64 to $96 \mathrm{~mm}$. of $\mathrm{Hg}$ systolic and 30 to $63 \mathrm{~mm}$. of $\mathrm{Hg}$ diastolic, and also showed that the pressure in the umbilical artery is approximately the same as that in the brachial artery. Ssladkoff (1903) using a modified Gaertner tonometer found the mean blood pressure in the first 24 hours to be $61 \mathrm{~mm}$. Hg; Rucker and Connell (1924) found the mean pressure at birth to be $55 \mathrm{~mm}$. $\mathrm{Hg}$ systolic and $40 \mathrm{~mm}$. $\mathrm{Hg}$ diastolic.

The rise in blood pressure in the first 12 days of life, rapid during the first three days and slower thereafter, is in keeping with the findings of Ssladkoff (1903), Balard (1912), Reis and Chaloupka (1923), and Woodbury et al. (1938). Ssladkoff also showed that the blood pressure ceases to rise after one month and that it rises very little from then until the age of 7 or 8 years.

Weight. Table 2 shows the mean blood pressure of infants in the three groups according to birth weight, 5 to $7 \mathrm{lb}$., 7 to $8 \mathrm{lb}$., 8 to $11 \mathrm{lb}$. The mean ages of the infants in each of these groups were practically identical, thus age was not a factor in the difference between them. These results are shown graphically in Fig. 4. The rise in blood pressure with increasing birth weight is statistically significant.

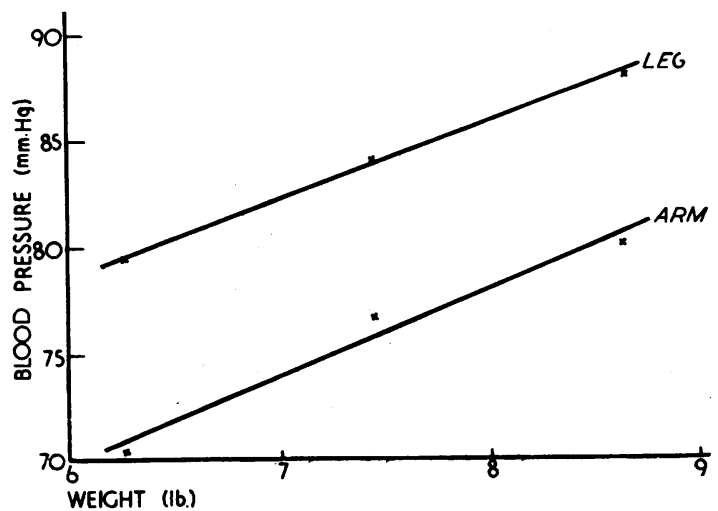

Fig. 4.
L. = Leg

The coefficient of correlation between birth weight and blood pressure (i.e., the mean of the four blood pressure readings taken over the 11-day period) was +0.297 . The standard error was 0.0945 . There is thus a significant positive correlation between blood pressure and birth weight.

It is possible that a factor in the higher blood pressure with increased birth weight is the greater length and girth of the upper arm relative to the size of the cuff. It is unlikely, however, that this wholly accounts for the difference, as Sullivan and Kobayashi (1955) found no correlation between blood pressure measured by the flush method and weight in a group of 160 infants whose ages ranged from 8 to 11 months. The varying length and girth of the upper arm in this group therefore did not influence the blood pressure.

Comparison of Blood Pressure in Leg and Arm. By applying the cuff to the upper arm and thigh the differential between arm and leg pressures, present in older children and in adults and probably also in the newborn (Robinow, Hamilton, Woodbury and Volpitto, 1939), is usually revealed. There is no such differential when the cuff is applied to the forearm and the lower limb (Goldring and Wohltmann, 1952; Reinhold and Pym, 1955).

In 231 out of 256 pairs of blood pressure recordings $(90.2 \%)$ the leg pressure was equal to, or higher than, the arm pressure; in the remaining 25 pairs $(9.8 \%)$ the leg pressure was lower than the arm pressure. One hundred and sixteen infants had pairs of blood pressures taken on two occasions at approximately weekly intervals. Out of the 232 pairs of pressures taken, 23 showed a reversed leg/arm pressure differential, but only twice was this reversed pressure present in the same infant on both occasions. In only six out of the 25 reversed blood pressures could crying (during the arm pressure but not during the leg pressure) have been a factor in the reversal. In the 25 reversed pressures the mean of the ratios expressing the leg 
TABLE 3

EFFECT OF CRYING ON BLOOD PRESSURE

\begin{tabular}{|c|c|c|c|c|c|c|c|c|c|c|}
\hline \multirow{3}{*}{$\begin{array}{l}\text { Age } \\
\text { (days) }\end{array}$} & \multicolumn{4}{|c|}{ Crying } & \multicolumn{4}{|c|}{ Not Crying } & \multicolumn{2}{|c|}{$\begin{array}{c}\text { Percentage Increase } \\
\text { on Crying }\end{array}$} \\
\hline & \multicolumn{2}{|c|}{ Arm } & \multicolumn{2}{|c|}{ Leg } & \multicolumn{2}{|c|}{ Arm } & \multicolumn{2}{|c|}{ Leg } & \multirow{2}{*}{ Arm } & \multirow{2}{*}{ Leg } \\
\hline & Mean & S.D. & Mean & S.D. & Mean & S.D. & Mean & S.D. & & \\
\hline $\begin{array}{l}0-3 \frac{1}{2} \\
6-11 \\
0 \cdot 11\end{array}$ & $\begin{array}{l}67 \cdot 4 \\
92 \cdot 6 \\
84 \cdot 9\end{array}$ & $\begin{array}{l}14 \cdot 4 \\
13 \cdot 5 \\
17 \cdot 8\end{array}$ & $\begin{array}{l}78 \cdot 4 \\
99 \cdot 9 \\
94 \cdot 4\end{array}$ & $\begin{array}{l}11 \cdot 7 \\
13 \cdot 5 \\
15 \cdot 8\end{array}$ & $\begin{array}{l}63 \cdot 9 \\
84 \cdot 4 \\
78 \cdot 1\end{array}$ & $\begin{array}{l}10 \cdot 7 \\
12 \cdot 5 \\
15 \cdot 1\end{array}$ & $\begin{array}{l}73 \cdot 4 \\
94 \cdot 1 \\
88 \cdot 7\end{array}$ & $\begin{array}{r}8 \cdot 5 \\
14 \cdot 3 \\
15 \cdot 8\end{array}$ & $\begin{array}{l}5 \cdot 5 \\
9 \cdot 7 \\
8 \cdot 7\end{array}$ & $\begin{array}{l}6 \cdot 8 \\
6 \cdot 2 \\
6 \cdot 4\end{array}$ \\
\hline
\end{tabular}

Mean increase in pressure on crying $=7 \cdot 5 \%$

pressure as a percentage of the arm pressure was $89.9 \%$ and the standard deviation was $8.3 \%$ (S.D. $\times 3=24.9 \%$ ). At three times the standard deviation therefore the lowest expected ratio would be $65 \%$ and this would occur very infrequently.

Thus, using the routine described here on normal newborn infants during the first 11 days of life there is only a 1 in 9 chance of the blood pressure in the legs being less than that in the arms, there is a 1 in 200 chance of the leg pressure being less than $75 \%$ of the arm pressure and only a 1 in 3,000 chance of the leg pressure being less than $65 \%$ of the arm pressure. Where two blood pressure estimations are carried out on the same infant with an interval of a few days between, in less than $5 \%$ of normal infants will the pressure in the legs be less than that in the arms on both occasions.

On the average the arm/leg blood pressure ratio for the various age groups specified in Table 1 remained constant at approximately 0.9 . The widest individual variations from the average, however, were seen in the first two days of life. After the fifth day no leg pressure was less than $85 \%$ of the arm pressure.

These standards are likely to have their greatest use in the diagnosis of coarctation of the aorta.

Effect of Crying. Fifty-two arm blood pressures and 54 leg pressures were taken on 67 crying infants. Each crying infant has been paired off with another of practically equal age and weight who was not crying at the time of blood pressure estimation, and the blood pressures compared. No infant was used more than once in the latter group. The results are shown in Table 3. Thus over the first
11 days of life crying increased blood pressure by less than $10 \%$ in the arm and less than $7 \%$ in the leg. None of these increases is statistically significant. These figures for crying and non-crying infants are given with some reserve as it was often difficult to decide whether an infant should be recorded as crying or not. Crying might cease just as the blood pressure estimation was about to begin or occur very transitorily during the estimation. Also the infant might be restless without actually crying.

By other methods crying has produced a significant effect. Woodbury et al. (1938) found that it raised the blood pressure by a mean percentage of 34 and Hoen (1952), measuring blood pressure by a method depending on transillumination of the external auricular artery, that it caused a rise ranging from 30 to $100 \%$. These comparisons were made on the same patient crying and not crying.

Sex. Table 4 shows the blood pressure in the arm and leg in males and females in the first three and a half days, from the sixth to eleventh day, and over the 11-day period. The mean weights and ages of the males and females of the two groups were practically the same. It will be seen that the sex of the infant has no influence on the blood pressure at this age.

Assessment of Accuracy of Results by the Flush Method. Some assessment of the accuracy of the flush method can be made by comparing the results obtained by this method with those obtained on direct catheterization on the assumption that the variability of the latter represents the true variability

TABLE 4

EFFECT OF SEX ON BLOOD PRESSURE

\begin{tabular}{|c|c|c|c|c|c|c|c|}
\hline Sex & $\underset{0-3 \frac{1}{2} \text { days }}{\text { Arm }}$ & $\begin{array}{c}\text { Arm } \\
\text { 6-11 days }\end{array}$ & $\begin{array}{c}\text { Leg } \\
0-3 \frac{1}{2} \text { days }\end{array}$ & $\begin{array}{c}\text { Leg } \\
\text { 6-11 days }\end{array}$ & $\begin{array}{c}\text { Average of } \\
\text { Arm and Leg } \\
0-3 \frac{1}{2} \text { days }\end{array}$ & $\begin{array}{l}\text { Average of } \\
\text { Arm and Leg } \\
\text { 6-11 days }\end{array}$ & $\begin{array}{c}\text { Average of } \\
\text { Arm and Leg } \\
0-11 \text { days }\end{array}$ \\
\hline $\begin{array}{l}\text { Male } \\
\text { Female }\end{array}$ & $\begin{array}{l}63 \cdot 2 \\
63 \cdot 3\end{array}$ & $\begin{array}{l}87 \cdot 2 \\
84 \cdot 6\end{array}$ & $\begin{array}{l}70 \cdot 5 \\
71 \cdot 3\end{array}$ & $\begin{array}{l}95 \cdot 2 \\
95.0\end{array}$ & $\begin{array}{l}67 \cdot 0 \\
67 \cdot 3\end{array}$ & $\begin{array}{l}91 \cdot 2 \\
89 \cdot 8\end{array}$ & $\begin{array}{l}79.4 \\
80.0\end{array}$ \\
\hline
\end{tabular}


of blood pressure. Woodbury et al. (1938) found the mean umbilical artery pressure in 24 infants at birth to be $80 \mathrm{~mm}$. $\mathrm{Hg}$ with a coefficient of variation of 10 . We took 24 pressure readings in the arms within eight hours of birth and the coefficient of variation of our results was 18 . Using the same mean as Woodbury et al., therefore, the range that would be expected by the flush method would be 51 to $109 \mathrm{~mm}$. of $\mathrm{Hg}$ as compared with the true range of 64 to $96 \mathrm{~mm}$. of $\mathrm{Hg}$.

The actual range of our under-eight-hour pressure readings extended over $43 \mathrm{~mm}$. $\mathrm{Hg}(42-85)$; that of Schaffer (1955), using the method of impendence plethysmography on 24 infants at birth, extended over $50 \mathrm{~mm}$. $\mathrm{Hg}$ (52-102).

Thus it would appear that the flush method, although not so accurate as direct measurement, and not so accurate as the auscultatory method, which in the older child or adult gives results closely comparable with direct pressure recordings, is yet sufficiently accurate to be a useful clinical guide. The range of results by this method might be further narrowed by ensuring that all pressures were taken with the infant quiet.

In the newborn infant, pressure readings obtained in the upper arm with a 1-in. cuff show more variation than those obtained with a 2 -in. cuff (Reinhold and Pym, 1955; Schaffer, 1955), but are most truly comparable with direct readings of the systolic pressure (Woodbury et al., 1938). We used a 2-in. cuff and the readings which we have obtained are thus probably below the systolic pressure. They are likely, however, to be fairly close to the mean systolic-diastolic pressure as our mean arm pressure by the flush method in the first eight hours $(60 \mathrm{~mm}$. Hg) agrees closely with the mean systolicdiastolic pressure $(63 \mathrm{~mm}$. $\mathrm{Hg})$ observed by Woodbury et al. on direct measurement.

\section{Summary}

Five hundred and thirteen blood pressure estima- tions have been carried out on 143 newborn infants (aged 0-11 days) using the flush technique.

The technique is described.

An assessment is made of the accuracy of the method and it is concluded that, although it is less accurate than the auscultatory method in the older child or adult, it is a useful clinical procedure.

The pressures given by the method described represent approximately the mean systolic-diastolic blood pressure.

During the first 11 days of life blood pressure increases significantly with age and shows a positive correlation with birth weight.

The normal range of blood pressure in the first 11 days of life is given.

In $90 \%$ of readings the blood pressure in the leg is higher than that in the arm.

The probabilities of occurrence of various degrees of reversed arm/leg pressures which may be encountered in the normal newborn infant are given.

Crying was found to increase the blood pressure by an average of $7.5 \%$.

No sex difference was found.

We wish to thank Professor R. W. B. Ellis for his support.

We also wish to acknowledge the invaluable help given by Sister Stephen in carrying out the blood pressure estimations.

\section{REFERENCES}

Balard. P. (1912). C. R. Soc. Biol. (Paris), 73, 483. Quoted by Woodbury, R. A., Robinow, M. and Hamilton, W. F. (1938) Amer. J. Physiol., 122, 472.

Cappe, B. E. and Pallin, I. M. (1952). Anaesthesiology, 13, 648.

Goldring, D. and Wohltmann, H. (1952). J. Pediat., 40, 285.

Hoen, E. (1952). Z. Kinderheilk., 70, 441.

Reinhold, J. and Pym, M. (1955). Archives of Disease in Childhood,

Reis, R. A. and Chaloupka, A. J. (1923). Surg. Gynec. Obstet., 37, 206.

Robinow, M., Hamilton, W. F., Woodbury, R. A. and Volpitto, P. P. (1939). Amer. J. Dis. Child., 58, 102.

Rucker, M. P. and Connell, J. W. (1924). Ibid., 27, 6.

Schaffer A. I. (1955). Ibid., 89, 204.

Ssladkoff (1903). Blood Pressure in Children. St. Petersburg.

Sullivan, M. P. and Kobayashi, M. (1955). Pediatrics, 15, 84.

Woodbury, R. A., Robinow, M. and Hamilton, W. F. (1938). Amer. J. Physiol., 122, 472. 